\title{
The influence of temperature on the solubilization of phosphorus from the sewage sludge using Bacillus megaterium bacteria
}

\author{
Joanna Ciopińska ${ }^{1, *}$, Elżbieta Bezak-Mazur $^{1}$, and Renata Stoińska ${ }^{1}$ \\ ${ }^{1}$ The Faculty of Environmental, Geomatic and Energy Engineering, Kielce University of Technology, \\ al. Tysiąclecia Państwa Polskiego 7, 25-314 Kielce, Poland
}

\begin{abstract}
This paper presents the results of research on the influence of temperature on the course of phosphorus solubilization from sewage sludge using Bacillus megaterium bacteria. The research was performed on a sanitized sewage sludge from a biological-mechanical treatment plant, to which phosphorus bacteria were applied. The experiment was conducted in two different temperature conditions, i.e. 21 and $36^{\circ} \mathrm{C}$ throughout the period of 23 days. During this time, parameters such as $\mathrm{pH}$ value and the total count of mesophilic bacteria were measured. The performed analyzes revealed that phosphorus solubilization occurs in both cases, however, at $36^{\circ} \mathrm{C}$ the process occurs much faster.
\end{abstract}

\section{Introduction}

The development of civilization and the associated rapid growth of chemical substances introduced into the environment results in its degradation. Along with the increasing population, the demand for food production is also growing, which results in an increased sewage production. The sewage sludge is the residue after the sewage disposal process. In an unprocessed form, it constitutes a threat to the environment, the same as wastewater. These sediments, after appropriate processing, can be an invaluable material for the production of fertilizers, because their structure resembles soil humus. The composition of these sewage sludge is never the same. It depends on the type of the treated wastewater, its quantity, the share of industrial wastewater in municipal wastewater, the degree and the type of the applied purification process $[3,10]$. The problem associated with the agricultural use of sludge is high levels of heavy metals and pathogens that may occur in them. Excess heavy metals in the sewage sludge can cause changes in soil fertility and reduce the size and quality of crops. Municipal sewage sludge can be used for agricultural purposes, if they do not contain live parasitic eggs, as well as Salmonella bacteria. Acceptable amount of metals that may be present in the sewage sludge has been specified in the Regulation of the Minister of Environment of 6 February 2015 on municipal sewage sludge $[3,11]$. The approximate composition of sewage sludge after stabilization is given in Table 1.

\footnotetext{
${ }^{*}$ Corresponding author: j.k.ciopinska@gmail.com
} 
Table 1. Particular values of sludge composition after stabilization [10].

\begin{tabular}{|c|c|c|}
\hline \multicolumn{3}{|c|}{ Sludge stabilized } \\
\hline Parameter & Unit & Value \\
\hline $\mathrm{C}$ & $\%$ d.m. & 25.06 \\
\hline $\mathrm{N}$ & $\%$ d.m. & 4.24 \\
\hline $\mathrm{P}$ & $\%$ d.m. & 2.5 \\
\hline $\mathrm{K}$ & $\%$ d.m. & 0.5 \\
\hline $\mathrm{Ca}$ & $\%$ d.m. & 28000 \\
\hline $\mathrm{Mg}$ & $\%$ d.m. & 4600 \\
\hline $\mathrm{Pb}$ & $\%$ d.m. & 40 \\
\hline $\mathrm{Cd}$ & $\%$ d.m. & 2.4 \\
\hline $\mathrm{Zn}$ & $\%$ d.m. & 1000 \\
\hline $\mathrm{Cu}$ & $\%$ d.m. & 160 \\
\hline $\mathrm{Ni}$ & $\%$ d.m. & 18 \\
\hline $\mathrm{Cr}$ & $\%$ d.m. & 22 \\
\hline Ascaris sp.,Trichuris sp., & p./kg.d.m & 3 \\
\hline Toxocara sp. & \multicolumn{2}{|c}{} \\
\hline
\end{tabular}

One of the most important components of the sediment is phosphorus. It is the basic nutrient for plants, and its deficiency limits their growth. Therefore, additional quantities of phosphorus are added to the production of fertilizers. So far, phosphate rocks, which are a non-renewable source, have been used for this purpose. It is estimated that with the current level of exploitation of phosphate rocks, they will be depleted within 50-100 years [9, 14]. There are cases when, despite the use of fertilizers, satisfactory results are not achieved, because the introduced forms of phosphorus are not available for plants.

Phosphorus, unlike other macroelements, is assimilated by plants only in its soluble form, i.e. $\mathrm{HPO}_{4}^{2-}$ ions. The mobility of phosphorus in the soil is limited, which is caused by the fact that it is not very accessible for living organisms. As a result of precipitation processes with ions, i.e. $\mathrm{Al}^{3+}, \mathrm{Ca}^{2+}, \mathrm{Fe}^{3+}$ or $\mathrm{Mg}^{2+}$, slightly soluble salts are formed, which inhibit the migration of this element. The amount of phosphorus available for living organisms depends on the $\mathrm{pH}$ value of the soil. At slightly acidic $\mathrm{pH}$ value, i.e. about 5 , it occurs most in the form of $\mathrm{HPO}_{4}{ }^{2-}$ ions, which can be immediately absorbed by the plants. In soils of neutral or alkaline reaction, containing large amounts of $\mathrm{Ca}^{2+}$ ions, occur reactions with superphosphate. In acidic soils with significant amounts of $\mathrm{Al}^{3+}$ and $\mathrm{Fe}^{3+}$ ions, insoluble $\mathrm{AlPO}_{4}$ and $\mathrm{FePO}_{4}$ compounds are formed. As a result, phosphorus is re-established in soil solutions, which means that there are no forms that can be absorbed by plants despite the soil nourishment with fertilizers containing phosphorus $[1,5]$. Phosphorus in soil solution occurs in three forms, depending on its availability to plants. The first of these is active phosphorus, occurring in the soil in the form of $\mathrm{PO}_{4}{ }^{3-}, \mathrm{HPO}_{4}{ }^{2-}, \mathrm{H}_{2} \mathrm{PO}^{4-}$ ions, separated as a result of the dissociation of orthophosphoric acid. The next form is mobile phosphorus. These are the most common phosphates of aluminum, iron, calcium, calcium and magnesium hydrogen phosphates and wivianite. The mobile phosphorus also includes compounds of this element, which are adsorbed on the surface of iron and aluminum oxides, present in the hydrated form, adsorbed on calcium carbonate molecules and some organic compounds, i.e. phospholipids, phytate or nucleic acids. The last form is reserve phosphorus, which includes apatite, variscite, strengit and phosphorite.

The uneven ratio of soluble to insoluble forms of this element in the soil is an environmental problem. It was found that even in soils rich in phosphorus only a small part of it is available for plants, i.e. about $0.1 \%$ [6]. In addition, the production costs of chemical fertilizers are high, and due to the depletion of phosphate resources, their use becomes imperative. Therefore, the possibility of using insoluble phosphorus contained in soil and sewage sludge is being sought. Phosphorus bacteria, PSB (called Phosphorus Solubilizing 
Bacteria) prove to be helpful in this case. These species have the natural potential to dissolve phosphorus, both organic and inorganic. Particular attention is focused on microorganisms which solubilize mineral phosphorus. Solubilization is the transformation of inorganic hardto-access forms into bioavailable ones. Using them as inoculums allows increasing the uptake of this element by plants $[6,7,9]$.

In recent years, the production of phosphate fertilizers containing strains of phosphorus solubilizing microorganisms (PSM) has been started. Application of these biopreparations allows the use of phosphorus contained in the soil, without the need to introduce additional quantities. The most popular bio-fertilizer available on the global market include Symbion $\mathrm{P}$, which contains microorganisms such as Bacillus megaterium, Bacillus polymyxa, Pseudomonas striata, as well as the fungus belonging to PSM Aspergillus sp. Another biopreparation is B6 (OMEX), containing strains of bacteria of the genus Bacillus, i.e. B. subtilis, B. pumilis, B. megaterium, B. laterosporus, B. chitonosporus and B. lichenisporus $[8,15]$.

The aim of the research was to select appropriate temperature conditions for phosphorus solubilization in sewage sludge, in order to effectively recover this element. For this purpose bacteria of the genus Bacillus megaterium, naturally occurring in the soil were used.

\section{Methodology}

For the purposes of the experiment, the sludge from the mechanical-biological treatment plant was used. Processing of the sludge is performed using the activated sludge method, taking into account nitrification, denitrification, biological and chemical dephosphatation. Mesophilic fermentation of sewage sludge separated in settling tanks is carried out in closed fermentation chambers. The stabilized sludge is mechanically dewatered on the belt presses and then dried in a column dryer. After stabilization the sewage sludge was hygienized with a dose of $0.2 \mathrm{~kg} \mathrm{CaO} / \mathrm{kg} . \mathrm{s} . \mathrm{m}$. Then, the samples were prepared, where $0.5 \mathrm{~g}$ of hygienized sludge was weighed into each $200 \mathrm{~cm}^{3}$ flask, afterwards a $150 \mathrm{ml}$ of medium with applied Bacillus megaterium bacteria were poured. The initial bacterial content was checked in sewage sludge. This medium did not contain phosphorus compounds, the only source of this element was sewage sludge. The prepared samples with the tested suspension were divided into two parts; the first part was placed in a thermostat at $36^{\circ} \mathrm{C}$, the second part was placed in a laminar chamber at $21^{\circ} \mathrm{C}$. The $\mathrm{pH}$ value of all samples was measured every day. In the initial phase of the process, the $\mathrm{pH}$ was measured every $2-4$ hours and at the end of the experiment once a day. For this purpose, the "METLER TOLEDO" pH meter was used. The analysis of the number of mesophilic bacteria was determined using serial dilution method. For this purpose, $1 \mathrm{ml}$ of suspension was collected each day for 14 days from each of the flasks, previously mixed using a Sky line shaker. The prepared suspension was introduced by a pipette into a Petri dish and poured into a liquid nutrient broth and incubated at $36^{\circ} \mathrm{C}$ for 24 hours. Finally, bacterial colonies were counted and the result was calculated depending on the dilution of the suspension. At the same time, the analysis of the amount of phosphorus assimilated by microorganisms was also performed. For this analysis, sequential filtration consisting of two stages was used. The first one separates the microorganisms contained in the liquid medium using glass wool. Then, the suspension was filtered through a membrane filter using vacuum filtration. Subsequently, the filter was exposed to mineralization with royal water. After cooling the samples, the $\mathrm{pH}$ was corrected using $10 \mathrm{M} \mathrm{NaOH}$ until the $\mathrm{pH}$ reached 3-10. Finally, the determination of phosphorus in the mineralized samples was carried out according to the standard for the determination of total phosphorus and orthophosphate [PN-EN-ISO 6878: 2006] using a PERKIN ELMER UV-VIS Lambda 25 spectrophotometer. 


\section{Results and discussion}

\subsection{Changes in the $\mathrm{pH}$ value in the tested suspension}

The analysis of $\mathrm{pH}$ changes is shown in the graph below (figure 1).

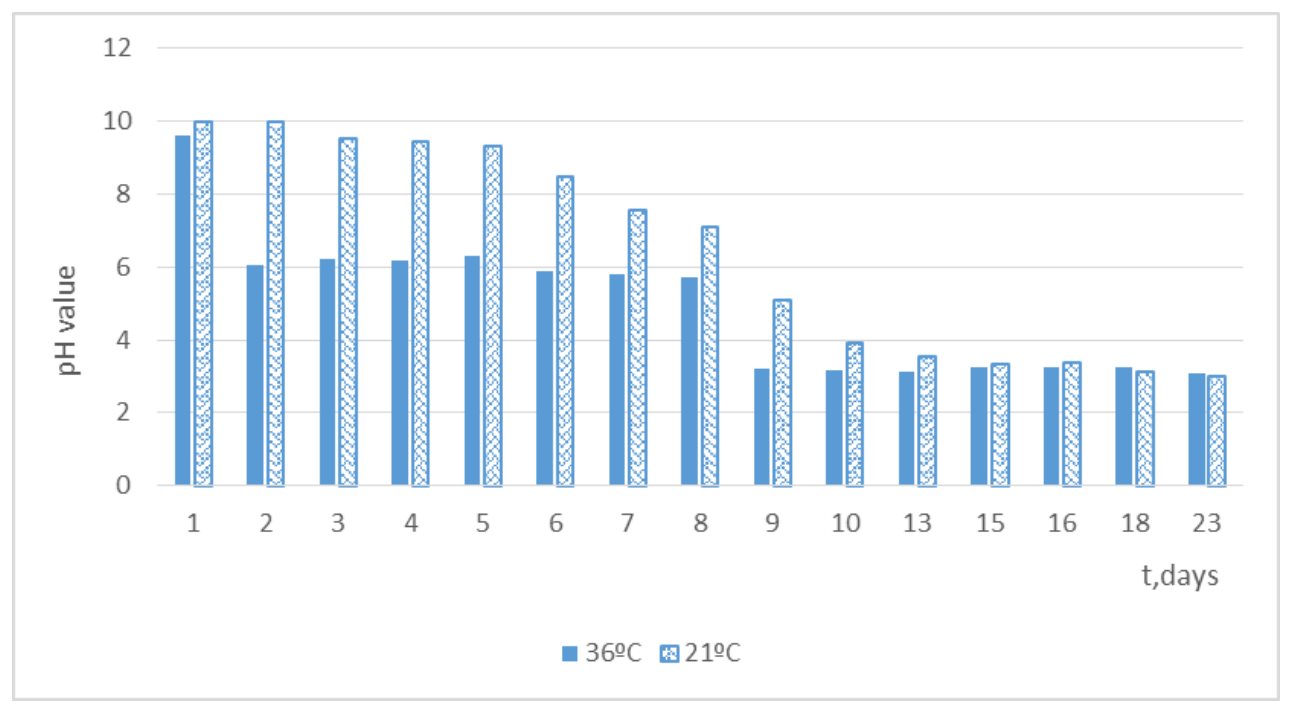

Fig. 1. The changes in the $\mathrm{pH}$ value during the process.

During the 23 days of testing, a significant decrease in $\mathrm{pH}$ was observed. The sewage sludge was hygienized with a high dose of calcium oxide, therefore the initial $\mathrm{pH}$ value was in the range from 9.69 to 10 . In the suspension submitted to $36^{\circ} \mathrm{C}$ after the first day of the experiment, the $\mathrm{pH}$ dropped by about 3 units, and at the turn of the $8^{\text {th }}$ and $9^{\text {th }}$ day the reaction was down by another 3 units and remained at a similar level to the end of the experiment. In the case of the suspension stored at $21{ }^{\circ} \mathrm{C}$, the process was much slower, because only on the $9^{\text {th }}$ day of the experiment, a diametric decline in $\mathrm{pH}$ was observed, which slightly changed to the end of the observations. The process came much faster at a higher temperature. The rise of temperature stimulates microbes, which incites metabolic processes by increasing the enzyme activity. The bacteria used for research produce organic acids, such as lactic, citric or propionic acid, which probably caused such a significant change in $\mathrm{pH}$ value $[7,13]$.

\subsection{Number of mesophilic bacteria}

Mesophilic microorganisms develop best at temperature for remove, i.e. $35-37^{\circ} \mathrm{C}$ [4]. Mesophiles also includes the Bacillus megaterium strain. For the purpose of the experiment conducted under two temperature conditions, i.e. 21 and $36^{\circ} \mathrm{C}$, the number of mesophilic bacteria was analyzed and the growth phases of the bacterial culture in the tested suspension were determined. The results of analyzes are presented in Table 2. 
Table 2. Number of mesophilic bacteria grown at $36^{\circ} \mathrm{C}$ and $21^{\circ} \mathrm{C}$ and change in the amount of phosphorus assimilated by microorganisms during the experiment.

\begin{tabular}{|c|c|c|c|c|c|}
\hline Days & 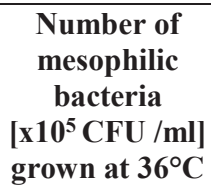 & $\begin{array}{c}\begin{array}{c}\text { Number of } \\
\text { mesophilic } \\
\text { bacteria }\end{array} \\
{\left[x 10^{3} \mathrm{CFU} / \mathrm{ml}\right]} \\
\text { grown at } 21^{\circ} \mathrm{C}\end{array}$ & Days & $\begin{array}{c}\mathrm{P} \text { assimilated } \\
\text { at } 36^{\circ} \mathrm{C} \\
(\mathrm{mg} / \mathrm{g} . \mathrm{d} . \mathrm{m})\end{array}$ & $\begin{array}{c}\mathrm{P} \text { assimilated } \\
\text { at } 21^{\circ} \mathrm{C} \\
(\mathrm{mg} / \mathrm{g.d} . \mathrm{m})\end{array}$ \\
\hline 1 & 2100 & 2100 & 0.167 & 0.5776 & 0.351918 \\
\hline 2 & 8200 & 5700 & 0.33 & 0.56103 & 0.490448 \\
\hline 3 & 5500 & 4900 & 1 & 0.3584 & 0.63194 \\
\hline 4 & 9625000 & 4000 & 2.167 & 0.1326664 & 0.3488904 \\
\hline 5 & 10715000 & 4100 & 3.167 & 0.2422388 & 0.1879696 \\
\hline 6 & 83000000 & 4283 & 4.167 & 0.354852 & 0.2169648 \\
\hline 7 & 71000000 & 4063 & 5.167 & 0.2526888 & 0.258594 \\
\hline 8 & 50000000 & 5500 & 6.167 & 0.5625984 & 0.6094812 \\
\hline 9 & 22500000 & 40000 & 8.167 & 0.576936 & 0.727272 \\
\hline 10 & 435000 & 44600 & 9.167 & 0.6566064 & 0.7263256 \\
\hline 11 & 341000 & 471000 & 13.167 & 0.667244 & 0.9215072 \\
\hline 12 & 85000 & 280000 & 14.16 & 0.8549808 & 0.8387224 \\
\hline 13 & 550000 & 75800 & 22.16 & 0.16404 & 0.209272 \\
\hline
\end{tabular}

Based on Table 2 (columns 1-3), diagrams (Fig. 2 and Fig. 3) were made to interpret the results.

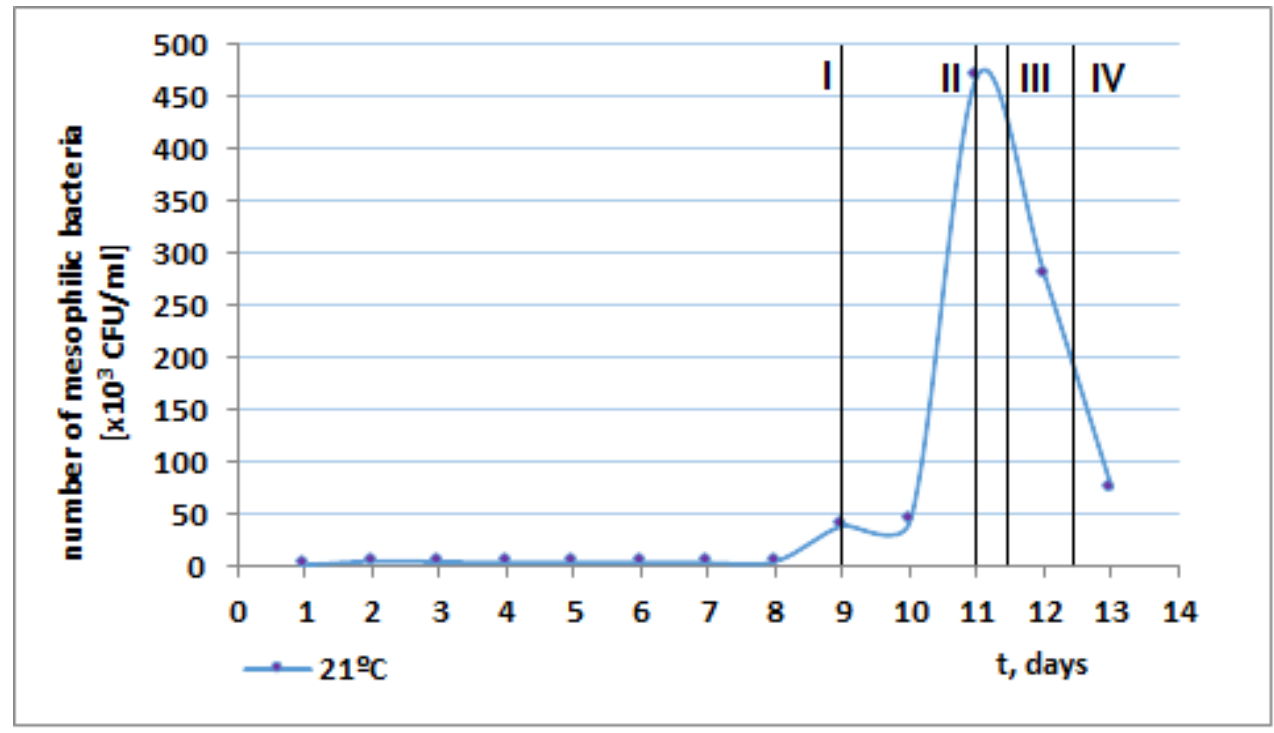

Fig. 2. Growth stages of mesophilic bacteria in suspension at $21^{\circ} \mathrm{C}$. 


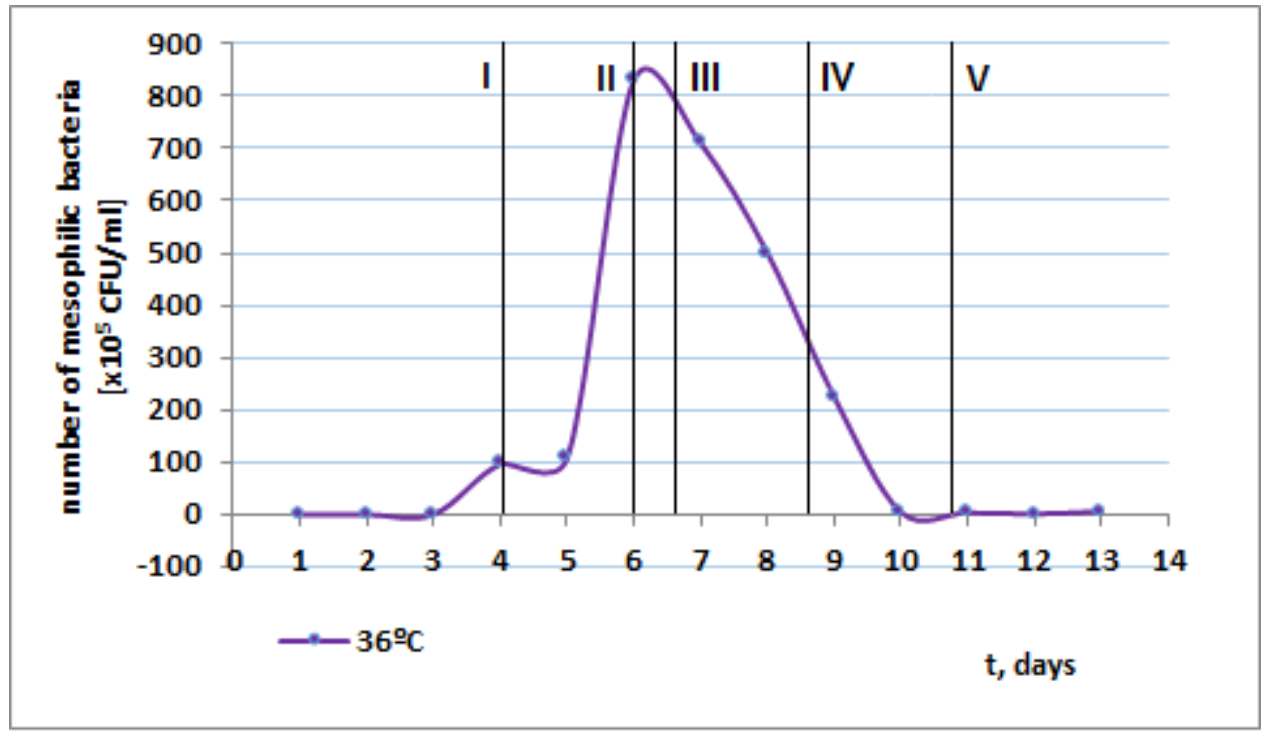

Fig. 3. Growth stages of mesophilic bacteria in suspension at $36^{\circ} \mathrm{C}$.

Comparison of these graphs allows to conclude that at $36^{\circ} \mathrm{C}$ the bacteria multiply faster and there are definitely more of them than the microorganisms grown at $21^{\circ} \mathrm{C}$. This is due to the high initial $\mathrm{pH}$ value caused by high dose of $\mathrm{CaO}$, lack of mixing and too low temperature for microorganisms kept in the laminar chamber.

Phase I is the stagnation phase. Bacteria at this stage adapt to the new environment. The length of the process depends on the conditions in which the microorganisms are located. In the case of bacterial culture at $21^{\circ} \mathrm{C}$, the stagnation phase lasted 9 days, and at $36^{\circ} \mathrm{C} 4$ days.

Phase II, the phase of logarithmic growth, is characterized by intense metabolism, followed by cell division. The number of bacteria increases in exponential progress. In this phase of growth, microorganisms are the most sensitive to environmental factors [12]. In both cases, i.e. $21^{\circ} \mathrm{C}$ and $36^{\circ} \mathrm{C}$, this phase lasted 3 days.

Phase III, the phase of equilibrium, is characterized by a constant level of cell number. As a result of insufficient amounts of nutrients, the cells exhaust their own back-up material. At $21^{\circ} \mathrm{C}$, this phase lasted less than 24 hours, and at $36^{\circ} \mathrm{C}$ one day.

Phase IV, phase of dieback. The number of living cells is decreasing, the processes of self-dissolution of bacteria under the influence of their own enzymes begin. Cell division does not occur. This stage for a temperature of $36^{\circ} \mathrm{C}$ lasted about 3 days, while at $21^{\circ} \mathrm{C}$ it did not end in the planned duration of the experiment.

Phase V, the sleep phase, i.e. the stage at which the cells die completely. Some of them change into spore forms. For a higher temperature of the process, this stage occurred after 11 days, for the lower one this stage was not observed $[4,12]$.

The analysis of the presented results allows to state that in both cases the process going on very rapidly. Although at a lower temperature, the stagnation phase lasts much longer, however, the moment the microorganisms are adapted to the environment, the process is more efficient. A quick transition from the equilibrium phase to the dieback phase can be caused by the production of organic acids, which lowered the $\mathrm{pH}$ to about 3 . Such acidic reaction of the environment may not be favorable for microorganisms. In addition, phosphorus, which was a nutrient for the applied bacteria, could also be exhausted. Observation of such a large drop in the $\mathrm{pH}$ level during the course of the tests means that in both cases the phosphorus solubilization process took place and that it occurs faster at $36^{\circ} \mathrm{C}$. 


\subsection{Analysis of the amount of phosphorus assimilated by microorganisms}

Simultaneously with the assessment of the number of bacteria, an analysis of the amount of phosphorus assimilated by the bacteria applied to the sediment was made for each sample [2]. The results of this analysis are shown in Table 2 (columns 4-6) for two different temperature conditions.

In the samples placed in the incubator $\left(36^{\circ} \mathrm{C}\right)$, the bacteria took small amounts of phosphorus at the beginning of the process. Then there was a drop, which lasted until the third day. This is related to the ongoing stagnation phase (Fig. 3), where microorganisms have adapted to new conditions. After this time there was an increase in the assimilation of this element, which lasted until the 14th day of the experiment, despite the decreasing number of bacteria (Fig. 3). This can be explained by the fact that not all microorganisms were at the same stage of development, and when some of them went into a dieback phase, the others started the logarithmic growth phase (Fig. 3).

As in the case of an experiment carried out at a higher temperature, in tests placed in a laminar chamber $\left(21^{\circ} \mathrm{C}\right)$, there was a slight assimilation of phosphorus by microorganisms in the first hours of the process. After that time there was a significant drop, which lasted until day 5. Assimilation of phosphorus began before the end of the stagnation phase and continued also during the bacteria die-off stage (Fig. 2).

\section{Conclusion}

The detailed analysis of changes in the $\mathrm{pH}$ value, the number of mesophilic bacteria and the amount of phosphorus assimilated by microorganisms allowed to formulate the following conclusions:

- Bacillus megaterium bacteria can solubilize phosphorus from sewage sludge, submitted to hygienization with a large dose of calcium oxide. In addition, this process takes place at both $21{ }^{\circ} \mathrm{C}$ and $36^{\circ} \mathrm{C}$. In both cases, the environment was acidified.

- The selection of different temperature conditions allowed the conclusion that solubilization occurs much faster at a higher temperature. This is also confirmed by the fact that in the samples placed in the incubator $\left(36^{\circ} \mathrm{C}\right)$ there was a significant increase in the number of bacteria in relation to the experiment conducted in the laminar chamber $\left(21^{\circ} \mathrm{C}\right)$. The number of mesophilic bacteria in the final phase of logarithmic growth at $36^{\circ} \mathrm{C}$ was as much as $83000000 \times 10^{5} \mathrm{CFU} / \mathrm{ml}$, whereas at $21^{\circ} \mathrm{C}$ the colony counted only $471000 \times 10^{3} \mathrm{CFU} / \mathrm{ml}$ (Table 2 ).

- Undoubtedly, phosphorus is assimilated by microorganisms under both temperature conditions. At the temperature of $36^{\circ} \mathrm{C}$, this process occurs faster and also takes less time. It can therefore be concluded that a higher temperature has a better effect on its course.

In conclusion, it is recommended to carry out the phosphorus solubilization process from sewage sludge at a higher temperature, because it is then more efficient and the higher temperature shortens its duration.

\section{References}

1. E. Bezak-Mazur, R. Stoińska, Arch. of W. Managm. and Env. Prot. 15, 3, 33-42 (2013)

2. E. Bezak-Mazur, R. Stoińska, B. Szeląg, Arch. Civ. Eng. Env. 4, 81-87 (2015)

3. J. Bień, Sewage sludge, theory and practice (Częstochowa Univ. of Tech., 2007) 
4. J. Buczek, K. Buczek, Outline of general microbiology (Lublin, 2000)

5. Collective work, Chemistry: phosphorus compounds in chemistry, agriculture, medicine and environmental protection (Univ. of Eco. in Wroclaw, 2008)

6. Dhankhar, Sheoran, et al. IJDR. 3, 9, 31-36 (2013)

7. M. Khan, A. Zaidi, M. Oves, Bacteria in agrobiology: crop productivity (Berlin, 2013)

8. E. Kurek, E. Ozimek, Adv. in Agr. Sci. 2, 85-95 (2008)

9. K. Mohammadi, Res. and Env. 2, 1, 80-85 (2012)

10. A. Ociepa-Kubicka, P. Pachura, Rocz. Ochr. Środ. 15, 2267-2278 (2013)

11. Polish Journal of Laws of 2015, item 257 (The Regulation of the Minister of the Environment dated 6 February 2015 on municipal sewage sludge, 2015)

12. H.G. Schlegel, General microbiology (PWN, 2005)

13. S.B. Sharma, R.Z. Sayyed, M.H. Trivedi, T.A. Gobi, Spr. Pl. 2, 587, 1-14 (2013)

14. A. Szaja, Rocz.Ochr. Środ. 15, 361-370 (2013)

15. http://www.tstanes.com/products-symbion-p.html dated 01/12/2017 